\title{
PERTUMBUHAN KREATIVITAS SISWA MELALUI PROGRAM EKSTRAKULIKULER DI SEKOLAH DASAR
}

\author{
Balqis Syifa Fauziyyah \& Silfia \\ Universitas Muhammadiyah Tangerang \\ balqissyifa237@gmail.com,silfi2031@gmail.com
}

\begin{abstract}
Extracurricular activities have an important role especially in character education especially the character of student creativity. Of the several types of extracurricular activities available, Scouting, Pencak silat and Drum Band is an alternative extracurricular program that can foster student creativity. Scouting activities, Pencak silat and Drum Band can belp students develop their creativity. Students can express themselves through line-up exercises, self-defense training, playing music, etc. In the context of the world of education, character education is very necessary to instill creative attitudes to students. But the space to give birth to creative ideas for students is still minimal. For this reason, the existence of extracurricular activities provides space for students to grow their creativity. The focus of this study aims to find out how to apply, plan, implement, evaluate, support and inbibit the character education of students' creativity growth through extracurricular activities. Through a qualitative approach, this research seeks to uncover the phenomena of efforts to grow student creativity through extracurricular activities in elementary schools. Data revealed through observation techniques, interviews and documentation. The data obtained is then analyzed using qualitative analysis, through three stages: data reduction, data display, and data verification. Based on the results of the interpretation of the research data, it shows that student creativity grows and develops optimally through extracurricular using the 4P strategy (Personal, Driving, Process, Products) and peer tutoring methods. But still found lack of appreciation from the school towards the work of students and infrastructure that must be updated and equipped.
\end{abstract}

Keywords: Student Creativity, Extracurricular

\begin{abstract}
Abstrak: Kegiatan ekstrakurikuler memiliki peranan penting khususnya dalam pendidikan karakter terutama karakter kreativitas siswa. Dari beberapa jenis ekstrakurikuler yang ada, Pramuka, Pencak silat dan Drum Band merupakan salah satu alternatif program ekstrakurikuler yang dapat menumbuhkan kreativitas siswa. Kegiatan Pramuka, Pencak silat dan Drum Band dapat membantu siswa mengembangkan kreativitasnya. Siswa dapat mengekspresikan dirinya melalui latihan baris -berbaris, latihan bela diri, bermain music, dll. Dalam konteks dunia pendidikan, pendidikan karakter sangat diperlukan untuk menanamkan sikap kreatif kepada siswa. Namun ruang gerak untuk melahirkan ide kreatif bagi siswa masih minim. Dengan alasan itu, adanya kegiatan ekstrakurikuler memberikan ruang bagi siswa untuk menumbuhkan kreativitasnya. Adapun fokus penelitian ini bertujuan untuk mengetahui bagaimana penerapan, perencanaan, pelaksanaan, evaluasi, pendukung dan hambatan pendidikan karakter penumbuhan kreativitas siswa melalui ekstrakurikuler. Melalui pendekatan kualitatif, penelitian ini berusaha mengungkap fenomena upaya penumbuhan kretivitas siswa melalui kegiatan ekstrakurikuler di sekolah dasar. data diungkap melalui teknik observasi, wawancara dan dokumentasi. data yang diperoleh kemudian dianalisis dengan menggunakan analisis kualitatif, melalui tiga tahap: reduksi data, display data, dan
\end{abstract}

Fondatia : Jurnal Pendidikan Dasar

Volume 4, Nomor 1, Maret 2020; 35-40

https://ejournal.stitpn.ac.id/index.php/fondatia 
verifikasi data . Berdasarkan hasil interpretasi terhadap data penelitian, menunjukkan bahwa kreativitas siswa tumbuh dan berkembang secara optimal melalui ekstrakurikuler dengan menggunakan strategi 4P (Pribadi, Pendorong, Proses, Produk) dan metode tutor sebaya. Tetapi masih di temukan kekurangan dari apresiasi pihak sekolah terhadap hasil karya siswa dan sarana prasarana yang harus diperbaharui dan dilengkapi.

Kata Kunci: Kreativitas Siswa, Ekstrakulikuler

\section{PENDAHULUAN}

Pendidikan merupakan hal yang penting dalam kehidupan. Melalui pendidikan diperoleh pengetahuan dan pemahaman tentang perubahan karakter maupun perilaku yang mampu mengembangkan dan membentuk watak yang bermartabat dan mecerdaskan kehidupan bangsa.

Berdasarkan Undang-Undang No.20 Tahun 2003 tentang sistem pendidikan nasional, Bab II pasal 3: Pendidikan nasional berfungsi untuk mengembangkan dan membentuk watak serta peradaban bangsa yang bermartabat dalam rangka mencerdaskan kehidupan bangsa, hal ini bertujuan untuk mengembangkan potensi peserta didik agar menjadi manusia yang beriman dan bertakwa kepada Tuhan Yang Maha Esa, berakhlak mulia, sehat berilmu, cakap, kreatif, mandiri, dan menjadi warga Negara yang demokrasi serta bertanggung jawab.

Agar tercapainya tujuan pendidikan nasional salah satunya yaitu mengembangkan potensi kreativitas siswa. Kreativitas merupakan suatu aktivitas atau kemampuan seseorang yang meciptakan suatu gagasan pemecahan masalah atau ide

ide berupa produk baru yang efektif dan bersifat imajinatif.

Oleh sebab itu kreativitas sangat penting bagi siswa karena berpengaruh terhadap totalitas kepribadian seseorang. Kreativitas merupakan bagian dari kajian pendidikan karakter sehingga kreativitas merupakan salah satu aspek penting dalam pendidikan karakter.

Pendidikan karakter di Sekolah Dasar merupakan salah satu awal penumbuhan karakter siswa terutaman pada karakter kreatif. Oleh sebab itu peran lembaga pendidikan menjadi sangat penting dalam hal membentuk karakter siswa. 
Namun, pada kenyataannya menurut (Wibowo, 2016) Berdasarkan temuan riset Richard Florida dkk dalam The Global Creativity Index 2015 (GCI, 2015) posisi Indonesia sangat rendah, yaitu peringkat ke 67. Riset terkait dengan indeks GCI ini mengukur tiga aspek utama yaitu : technology, talent, dan tolerance.

Berdasarkan hasil riset tersebut megisyaratkan ada yang keliru dalam proses pendidikan di Indonesia. Kreativitas siswa tidak mendapatkan ruang gerak untuk melahirkan ide kreatif baik di sekolah maupu lingkungan sosial. Pendidikan kreativitas masih minim diajarkan kepada siswa.

Selain itu, dari pikah sekolah masih banyak yang belum menyediakan wadah yang dapat menampung krativitas siswa, belum adanya fasilitasi dan sarana untuk menuangkan ide ide kreatifnya. Adapun proses pembelajaran masih berpusat pada guru, sehingga siswa hanya mengikuti apa yang di perintahkan oleh guru, siswa tidak memiliki kesempatan untuk mengekspresikan dirinya.

Berdasarkan permasalahan di atas, hal tersebut akan mampu diatasi dengan mengubah cara pembelajaran yang dilakukan oleh guru dengan melihat bagaimana pengajaran yang cocok atau sesuai dengan pengembangan pendidikan karakter siswa.

Pengembangan karakter bisa dilakukan melalui macam-macam kegiatan tambahan diluar jam sekolah, salah satu yang lazim dikenal yaitu kegiatan ekstrakurikuler.

Sejalan dengan hal tersebut (Sumaryadi, 2011, hlm. 6) menyatakan bahwa "kegiatan ekstrakurikuler merupakan kegiatan pendidikan di luar mata pelajaran untuk membantu pengembangan siswa sesuai dengan kebutuhan, potensi, bakat, dan minat mereka”.

Dari beberapa jenis ekstrakurikuler yang Ada; pramuka, pencak silat dan drum band merupakan salah satu alternatif program ekstrakurikuler yang dapat menumbuhkan kreativitas siswa. Dalam setiap drama atau teater terdapat pesan-pesan moral yang bisa disampaikan dengan cara yang menyenangkan. Kegiatan pramuka, pencak silat dan drum band dapat membantu siswa mengembangkan kreativitasnya dalam berkarya, siswa mengekspresikan dirinya melalui latihan bari-berbaris dan bermain musik. 
Berdasarkan studi ke lapangan, sekolah dasar di SDN Pakujaya 1, mewajibkan siswa SDN Pakujaya 1 untuk mengikuti ekstrakulikuler wajib yaitu, pramuka dan pencak silat. Sedangkan ekstrakulikuler pilihan yang banyak diminati para siswa adalah Drum Band. Pramuka sangat penting untuk siswa karena dapat melatih kemandirian, barisberbaris, melatih fisik dll.

Sedangkan pencak silat diwajibkan karena memang pencak silat adalah tradisi tradisional dari banten. Maka dari itu, pencak silat diwajibkan untuk mengembangkan tradi nenek moyang. Sedangkan drum band adalah ekstrakulikuler yang banyak diminati para siswa. SDN Pakujaya 1, pernah menjadi perwakilan sekolah dalam acara 17 agustus di kelurahan. Dengan jumlah 50 orang yang mengikuti drum band.

Berangkat dari pemikiran di atas, peneliti terdorong untuk melakukan penelitian tentang pendidikan karakter; penumbuhan kreativitas siswa melalui program ekstrakurikuler di sekolah dasar. Penelitian ini bertujuan untuk mengetahui bagaimana penerapan, perencanaan, pelaksanaan, evaluasi, pendukung dan hambatan pendidikan karakter kreativitas siswa melalui ekstrakurikuler teater.

\section{METODE PENELITIAN}

Penelitian ini bertujuan mengetahui penumbuhan kreativitas siswa melalui program ekstrakurikuler di sekolah dasar. Oleh karena itu, pendekatan yang tepat digunakan dalam penelitian ini adalah pendekatan kualitatif.

Menurut Moleong (2005, hlm.6) penelitian kualitatif adalah "Penelitian yang bermaksud untuk memahami fenomena tentang apa yang di alami oleh subjek penelitian misalnya perilaku, persepsi, motivasi, tindakan, dll”.

Penelitian ini menggunakan metode penelitian analisis deskriptif. Metode ini hanya memaparkan peristiwa atau aktivitas yang terjadi. Teknik pengumpulan data merupakan cara yang ditempuh dalam mengumpulkan data yang dibutuhkan untuk menjawab masalah penelitian. Pengumpulan data yang dilakukan dalam penelitian ini adalah menggunakan observasi, wawancara, dan dokumentasi.

Observasi dilakukan untuk mengetahui penumbuhan kreativitas siswa dan mengetahaui materi dan kegiatan apa saja yang dapat menumbuhkan kreativitas siswa. 
Selanjutnya teknik wawancara menggunakan tipe semi terstruktur. Peneliti membuat kisi-kisi dan pedoman wawancara, yang di wawancara diantaranya kepala sekolah, guru kelas. Dokumen yang di perlukan diantaranya data sekolah, gambar kegiatan, hasil karya seni siswa.

\section{HASIL DAN PEMBAHASAN}

Kondisi Penumbuhan Kreativitas Siswa melalui Program Ekstrakurikuler di Sekolah Dasar. karakter yang baik harus dilakukan dengan cara pembiasan yang baik pula. Salah satu bagaian dari pendidikan karakter adalah karakter kreatif. Upaya yang dilakukan untuk menumbuhkan kreativitas siswa dengan cara mengadakan kegiatan kreatif seperti pembiasaan di kelas dan kegiatan ekstrakurikuler. Dalam penumbuhan kreativitas siswa melalui program ekstrakurikuler teater menggunakan strategi 4P(pribadi, pendorong, proses, produk) serta metode tutor sebaya. Menurut Munandar (1999, hlm.26) proses kreativitas dirumuskan dalam 4P yaitu Pribadi, pendorong, Proses, dan Produk. Pribadi kreatif melibatkan diri dalam kegiatan kreatif, dengan dorongan dari diri sendiri dan lingkungan yang mendukung, sehingga mengalami proses mengeluarkan ide-ide yang dimilikinya kedalam bentuk karya dan menghasilkan produk keatif.

Menurut Anggraini (2014, hlm.4) Metode tutor sebaya adalah suatu metode yang memanfaatkan potensi siswa seperti kebribadian yang ramah, lancar berbicara, luwes, mudah bergaul, berprestasi baik, dan memiliki daya kreativitas yang baik untuk membimbing temannya agar dapat tertular potensi yang dimiliki siswa tersebut. Banyak ilmu dan pengalaman yang didapat oleh siswa melalui proses latihan. Selain itu siswa ikut aktif dalam mengembangkan seni budaya. 2. Perencanaan, Pelaksanaan, Evaluasi Penumbuhan Kreativitas Siswa melalui Program Ekstrakurikuler di Sekolah Dasar.

Program ekstrakurikuler teater di SDN Pakujaya 1 memiliki perencanaan mulai dari materi, indikator, tujuan, agenda kegiatan. Semuanya sudah direncanakan sedemikian rupa agar tercapainya misi sekolah. Dalam latihan rutin siswa mempelajari semua bidang yang ada dalam Ekstrakulikuler pramuka, pencak silat dan Drum Band. 
Proses latihan tersebut dilakukan secara bertahap, dilihat pula dari kemampuan siswanya. Apabila siswa sudah menguasai bidang yang sesuai dengan bakatnya siswa dapat bertukar pikiran dengan temannya seperi tutor sebaya. SDN Pakujaya 1, sudah memulai ekstrakulikuler pada kelas 3, dan saat itu juga siswa sudah diwajibkan mengikuti ekstrakulikuler wajib, seprti pramuka dan pencak silat. Sedangkan ektrakulikuler pilihan itu banyak,seperti; drum band,menjahit dll. Tapi siswa SDN Pakujaya 1, lebih berminat pada ektrakulikuler Drum Band, dan juga SDN Pakujaya 1, pernah menjadi perwakilan sekolah dalam acara 17 agustus di kelurahan.

\section{KESIMPULAN}

Kegiatan ekstrakurikuler memiliki peranan penting khususnya dalam pendidikan karakter terutama karakter kreativitas siswa. Dari beberapa jenis ekstrakurikuler yang ada, Drum Band merupakan salah satu alternatif program ekstrakurikuler yang dapat menumbuhkan kreativitas siswa. Dalam penumbuhan kreativitas siswa melalui program ekstrakurikuler memnggunakan strategi $4 \mathrm{P}$ (pribadi, pendorong, proses, produk) serta metode tutor sebaya. Kegiatan ini di dukung penuh oleh sekolah, orang tua dan guru pengajar, namun pihak sekolah masih kurang mengapresiasi hasil karya siswa serta terdapat hambatan guru dalam pola asuh yang di protes oleh orang tua sehingga harus adanya saling keterbukaan antara orang tua dan pelatih.

\section{DAFTAR PUSTAKA}

Anggraini, A. (2014). Peningkatan Kreativitas Belajar melalui Metode Pembelajaran Tutor Sebaya dalam Mata Pelajaran Bahasa Indonesia pada Kelas V SDN 1 JumapolaTabun Ajaran 2013-2014 .(Skripsi). Sekolah Sarjana, Universitas Muhammadyah Surakarta, Surakarta.

Sugiono. (2015). Metode Penelitian Kuantitatif, Kualitatif, dan RひD. Bandung: Alfabet. Wibowo, A. (2016, April Senin). Kreativitas dan Pendidikan Kita. Dipetik Januari 8, 2018, dari Media Indonesia:

http://mediaindonesia.com/news/read/38101/kreativitas-dan-pendidikankita/201604-04 